\title{
Economic performance and turnout at national and local elections
}

\author{
Rodrigo Martins ${ }^{a}$ \\ Universidade de Coimbra and GEMF \\ Francisco José Veiga ${ }^{b}$ \\ Universidade do Minho and NIPE
}

\begin{abstract}
This paper analyzes the impact of economic performance on voter turnout. We estimate an economic turnout model in which local economic variables are included in quadratic form, so that non-linear effects can be taken into account. We use panel datasets covering municipalities, from 1979 to 2005, and cross-sections of parishes (freguesias) to analyze the determinants of turnout at Portuguese municipal and legislative elections. The empirical results indicate that the performance of the national economy is important only in legislative elections and that the regional and local unemployment rates tend to have nonlinear relationships to turnout. The results obtained for Flemish municipalities also provide evidence in favor of a non-linear effect of unemployment on turnout.
\end{abstract}

Keywords: Turnout, local governments, elections, economic conditions

JEL Classifications: D72, H7

\section{Published version}

\footnotetext{
${ }^{a}$ Faculdade de Economia, Universidade de Coimbra, Av. Dias da Silva 165, 3004-512 Coimbra, Portugal. E-mail: rodrigom@fe.uc.pt.

${ }^{\mathrm{b}}$ Corresponding author: Francisco José Veiga, Escola de Economia e Gestão, Universidade do Minho, 4710-057 Braga, Portugal. E-mail: fjveiga@eeg.uminho.pt.
} 


\section{Introduction}

Since the 1980s, numerous studies have analyzed the determinants of voter turnout and various theories have emerged addressing the many different aspects of the theme (see Geys 2006a, 2006b and Blais 2006 for encompassing surveys). As it stands, the existing research has established some robust patterns. Sociological characteristics, especially age and education, have been consistently referenced as important explanatory factors (Blais 2000; Franklin 2004; Lijphart 1997). We also know relatively well why turnout is higher in some countries than in others. Comparative studies show that different Institutional arrangements embodied in electoral laws provide different turnout outcomes (Powell 1986; Jackman 1987; Jackman; Miller 1995). In general, the more accountable and competitive the political systems are, the larger is electoral mobilization.

However, regarding the effect of the economy on turnout, the literature provides mixed results and is far from reaching a consensus. Strong evidence is found supporting the idea that the economy affects how a person votes and a great deal of scholarly attention has been paid to the issue (Paldam 2004; Nannestad and Paldam 1994). Comparatively, studies analyzing if (and how) the economy affects whether a person votes or not are scarce and we find conflicting theories and inconsistent results. There is, however, relatively strong support for the hypothesis that turnout is higher in economically advanced countries (Blais and Dobrzynska 1998; Norris 2002; Fornos et al. 2004).

The main goal of this paper is to provide new insights and contribute to a better understanding of this relationship. Using five extensive datasets, we find robust empirical evidence indicating that economic conditions affect turnout rates in Portugal, not only at legislative elections (elections to the national assembly), but also at municipal elections. 
Moreover, the results support the hypothesis that the economy has non-linear effects on turnout. That is, the presence and magnitude of mobilization or withdrawal effects on turnout depend on economic performance. Concretely, there is greater turnout in good and bad times (mobilization effect), but participation rates are lower if the economy is neither too hot nor too cold: voters withdraw in a 'Goldilocks state'. These results are corroborated in a robustness test in which we use data from Geys and Heyndels (2006) on the 2000 Flemish municipal elections. Although these authors did not find evidence of a linear effect of the unemployment rate on turnout, there is evidence of a non-linear (U-shaped) effect when squared unemployment is also included as an explanatory variable.

We believe that the identification of non-linear effects of economic variables on turnout is a significant contribution to the literature. It is possible that many previous studies obtained mixed results for the effects of economic performance on turnout because the possibility that those effects are non-linear was not properly taken into account. ${ }^{1}$ We simultaneously analyze legislative and municipal elections, using similar variables, models and estimation methods, thus permitting a clear assessment of the differences and similarities between turnout behavior at first- and second-order elections.

The article is organized as follows. Section 2 discusses the relationship between turnout and economic conditions. Section 3 describes the model and dataset used. The panel data results are presented in section 4, while section 5 reports the cross-sectional results. Finally, conclusions are presented in section 6.

\footnotetext{
${ }^{1}$ This study also investigates the effects of standard socio-demographic and institutional variables. Although there are some studies that examine turnout at Portuguese elections from a sociological perspective (see, among others, Freire and Magalhães 2002), to the best of our knowledge, there are no articles focusing on the economic dimension nor using panel data techniques.
} 


\section{Turnout and the economy}

The literature provides two competing theories regarding the expected relationship between turnout and the economy. The first argues that people under economic strain are more prone to vote, in what Schlozman and Verba (1979) called a "mobilization" effect. In this view, people are encouraged to be more active politically (vote, protest, lobby...) because they blame the government for their economic hardships and wish to manifest their discontent regarding the government's policies. The "negative voting" theory (see Lau 1982) reinforces this argument as it posits that the political motivation to punish is greater than to reward; economic duress therefore should foster turnout.

The second theory argues the opposite. It assumes that voters respond to adverse economic conditions by withdrawing from the political process. The reason is that people suffering economic hardships face serious problems; they therefore tend to focus their efforts and attention on solving them and, as a result, pay less attention to external matters like politics. Rosenstone (1982) argues that this relationship holds, not only at the individual level, but also at the aggregate level, and some studies find evidence that especially the poor and the unemployed exhibit a markedly diminished capacity to participate in politics (Wolfinger and Rosenstone 1980; Caldeira et. al. 1985).

Along with these two competing explanations, the alternative of no effect is also possible. This idea seems to dominate, as we find a sizeable literature either not addressing the issue of economics effects or reporting evidence supporting the notion that economic conditions do not affect turnout (e.g., Fiorina 1978; Blais and Dobrzynska 1998; Blais 2000, Kostadinova 2003; Fornos et al. 2004).

However, a nil effect of the economy on turnout, as some studies report, is considerably different from a null effect. Radcliff (1992) points out that, as the two 
competing theories exhibit solid arguments but contradictory claims regarding the expected effect of the economic environment on turnout, the most likely scenario is a nil overall effect, because both withdrawal and mobilization effects may indeed occur simultaneously and thus cancel each other out.

The null effect hypothesis raises the question of whether economic variables are being properly introduced in the turnout function. Radcliff (1992) provides a first insight on the matter when observing that in developed countries adverse economic conditions tend to depress turnout, as Rosenstone (1982) suggests, but in the developing countries the opposite occurs. He argues that "the difference may be attributable to the stakes involved. In the absence of security programs the potential human costs of poor economic performance are much greater" (Radcliff 1992: 446). He found evidence that the effect of the economy is best modeled when interacted with a measure of social welfare programs and using a polynomial form.

In this paper we try to go further by testing the hypothesis that both withdrawal and mobilization effects exist simultaneously and that different degrees of economic performance provide different stimuli to voters. We posit that in good and bad times the mobilization effect dominates, as voters may wish to express their satisfaction/dissatisfaction with economic performance, while situations in which the economy is neither too hot nor too cold may cause the withdrawal effect to be dominant. These effects are consistent with the theory of expressive voting, according to which voting may be motivated by concerns other than the outcome of the election. ${ }^{2}$

\footnotetext{
${ }^{2}$ An early discussion of expressive voting can be found in Buchanan (1954). Fiorina (1976) distinguished expressive voting from instrumental voting (suggested by Downs 1957). For a recent survey of expressive political behavior, see Hamlin and Jennings (2011).
} 
Although an individual voter is aware that her vote has practically no chance of being decisive in a mass election, she may nevertheless desire to vote in order to express her satisfaction/dissatisfaction with the economic performance achieved by the incumbent government. As suggested by Hillman (2010), material losses due to expressive behavior (such as those incurred when voting) may be very small or zero, which implies that expressive voting may have a positive net impact on a voter's total utility. ${ }^{3}$

The motivation to vote expressively may vary with economic conditions and be more salient in good and bad times. We expect voters to feel more compelled to express their satisfaction/dissatisfaction when the economy is good/bad, as they may want to reward/punish the incumbent at the ballot box. When the economy is neither too hot nor too cold, alienation from the political process is a strong possibility, as voters may not be concerned enough about the economy to actually participate. Furthermore, the economy may not be a sufficiently salient issue to be relevant for the decision of whether to vote or not. $^{4}$

One way of modeling these effects is to use the economic variables in a quadratic form, as it allows the identification of increasing or decreasing marginal effects. We use this alternative in our analysis of turnout for the Portuguese elections. To conform to theoretical expectations the coefficients must result in an inverted U-shaped quadratic form for economic variables such as income or GDP (positive sign associated with the linear term and

\footnotetext{
${ }^{3}$ Hillman (2010) presents total utility as the sum of material utility and expressive utility. Voting implies a material loss, given the costs of voting and the low probability of affecting the outcome of the election, and a positive expressive utility, derived from a conception of civic duty or expressive confirmation of identity. Since the cost of voting is very small, the net effect of expressive voting on total utility may be positive.

${ }^{4}$ Due to the consumption cost of information, voters tend to be, on average, ignorant about the economy (see Aidt 2000). But, they may have a stronger incentive to become informed or experience larger changes in their personal finances, when the economy is performing better or worse than usual. Furthermore, the media may devote more attention to economic events in such situations. Thus, voters are more likely to be aware of economic conditions in good or bad times than when economic performance is as usual. In the latter case, voters are expected to be, on average, ignorant about the economy and it will be a less salient issue.
} 
a negative sign associated with the quadratic term) and exhibit the opposite shape for variables such as unemployment or inflation (negative sign associated with the linear term and a positive sign associated with the quadratic term).

\section{Data and model specification}

We use five extensive datasets to analyze the economic determinants of turnout. The first two are comprised of panel data for all mainland Portuguese municipalities ${ }^{5}$ (currently 278), ranging from 1979 to 2005. One dataset covers ten electoral periods for legislative elections and the other covers eight electoral periods for municipal elections. The third and fourth datasets are cross-sectional and pertain to the 2001 municipal elections and the 2002 legislative elections. They comprise all mainland parishes - freguesias $^{6}$ (a total of 4037). Yearly unemployment data are not available at the parish level, but because 2001 was a census year, data for the unemployment rate at both municipal and parish levels are available. This enables us to investigate the salience of the local unemployment rate at a much more disaggregated level than previous studies have attempted. Electoral results and political data used were all obtained from the Technical Staff for Matters Concerning the Electoral process (STAPE). Finally, in order to check if the results obtained with Portuguese data hold for other countries, we used the cross-sectional dataset of Geys and Heyndels (2006) for the 2000 Flemish municipal elections.

\footnotetext{
${ }^{5}$ Mainland Portugal is divided into 278 municipalities (municípios or concelhos). Usually, a municipality has the name of its biggest town or city or, in some cases, of its historically most important town or city. The municipality is, usually, considerably larger than the city or town after which it is named. Regarding our data set, between the restoration of democracy in 1974 and 1979 only one election was held at the municipal and legislative levels (both in April 1976). Data regarding the independent variables for the 1976 elections are effectively lost in the estimations due to the autoregressive nature of our model.

${ }^{6}$ Each municipality is subdivided into a variable number of parishes (freguesias). These are the lowest administrative units in Portugal.
} 
The empirical model used has an autoregressive component and is of the following form:

$$
\operatorname{TURN}_{i, E}=\alpha_{1} \operatorname{TURN}_{i, E-1}+\alpha_{2} E C O_{i, E}+\alpha_{3} E \mathrm{CO}_{i, E}^{2}+\alpha_{4} \text { Social }_{i, E}+\alpha_{5} \text { Institucional }_{i, E}+v_{i}+u_{i, E}
$$

where $T U R N_{i, E}$ is the number of votes in municipality/parish $i$ at election year $E$ as a share of the eligible population ${ }^{7}$ and $E C O_{i, E}$ is a set of economic variables. Then, to control for noneconomic determinants of turnout, we include one set of institutional variables and one set of socio-demographic regressors. Finally, $v_{i}$ is the fixed effect for municipality $i$, and $u_{i, E}$ is the error term. Equation (1) is estimated using panel data and using cross section data for a single election.

Regarding the economic variables, the national unemployment rate was obtained from the OECD's Main Economic Indicators. Data for the regional GDP (at the NUTS III level), and the unemployment rate at the freguesia and NUTS III levels ${ }^{8}$ were obtained from the Portuguese National Institute of Statistics (INE). The regional NUTS III unemployment rate was available only for 1991 and from 1999 onwards, thus reducing time variability and the number of observations in our sample. To overcome this difficulty, we estimated a proxy of the unemployment rate for the remaining years of the 1990s using the multiple imputation algorithm developed by Honaker and King (2010). ${ }^{9}$ There are no consistent time series data for unemployment available at the municipal level, however. To control for the labor market

\footnotetext{
${ }^{7}$ For municipal elections we use the turnout for Town Council elections, which are the ones that determine the mayor. Voters also cast their votes on the same day for the Municipal Assembly and for the Assembly of the freguesia.

${ }^{8}$ NUTS is a geocode standard for referencing the subdivisions of countries for statistical purposes, used within the European Union. In Portugal, a hierarchy of three NUTS levels is established. Continental Portugal corresponds to a NUTS I region, which is subdivided into five NUTS II regions. These five regions are then subdivided into 28 sub regions (NUTS III), each one comprised of several municipalities.

${ }^{9}$ This method is a bootstrapping-based algorithm particularly suited for tackling the problem of missing observations in panel data when $t<n$. It extracts relevant information from the observed portions of a data set by estimating a statistical model that includes a set of explanatory variables. This method was not used to solve the missing data problem with our demographic variables because the number of missing data points was very high and we had hardly any time consistent data for the independent variables.
} 
at the municipal level we use data on employment in private firms located in each municipality, which is available on the "Quadros de Pessoal" database of the Portuguese Ministry of Labor and Social Solidarity (MTSS). ${ }^{10}$ Also from this source, we use the real average municipal wage growth rate, available since 1985. As a measure of municipal income, we use Marktest's Sales Index, which reflects municipalities' wealth by taking into consideration the population, fiscal burden, electricity consumption, automobiles sales, and the number of banks and retail stores. ${ }^{11}$

To control for the municipalities' socio-demographic characteristics we include some of the typical explanatory variables found in empirical studies: population density, the illiteracy rate, the share of the resident population above 65 years old, and the percentage of the municipality's population employed in the tertiary sector. ${ }^{12}$ Data on Municipal population were obtained from the local authority's (Direcção Geral das Autarquias Locais $D G A L$ ) annual publication called Finanças Municipais (Municipal Finances). The illiteracy rate and the data on the percentage of the population in the tertiary sector were obtained from the Census operation of the Portuguese National Institute of Statistics (INE). Data were available for 1981, 1991 and 2001. As the evolution of this kind of variable over time is generally based on a stable trend, a constant growth rate was assumed to fill in the missing

\footnotetext{
${ }^{10}$ This is a yearly mandatory employment survey that covers almost all privately owned firms employing paid labor in Portugal (public servants and own employment are not included).

11 More concretely, the Sales Index (SI) is constructed according to the following equation:

$$
S I_{m}=0.2 \text { Pop }_{m}+0.8\left(\sum_{j=1}^{5} W_{m j}\right) / 5,
$$

where $\mathrm{Pop}_{m}$ is the share of municipality $m$ in the national population, and $W_{m j}$ is the weight of municipality $m$ in the country total regarding variable $j$ (the five variables considered are the fiscal burden, electricity consumption, number of cars sold, number of bank agencies, and number of retail commercial establishments). The values of the index are then normalized so that a value of 100 corresponds to the country average.

12 This refers to the classification of economic activities in three sectors: the primary, the secondary and the tertiary. The tertiary sector is characterized by the production of services instead of end products or raw materials.
} 
data. Data on population by age are obtained by assuming a constant growth rate for the period 1979-1989, on the basis of the 1970 and 1981 censuses; for the remaining years annual data was acquired from INE's resident population estimates. A larger population is expected to be associated with lower electoral turnout. Population measures are often used to check Downs's (1957) claim of a direct relationship between turnout and the probability of casting the decisive vote. In general, studies show that higher education is linked with greater participation (see Blais 2000). Therefore, one should expect the illiteracy rate to be negatively correlated with turnout. ${ }^{13}$ Regarding age, studies generally report it having a positive effect on turnout. However, as we use the population over 65 years old, this effect may be mitigated because, for older people, health issues may inhibit some from going to the polls.

The percentage of the population employed in the tertiary (services) sector may be viewed as a proxy for urbanization and, simultaneously, a measure of education, as white collar workers tend to be more educated than the average worker. We have no prior expectation regarding the sign of the coefficient associated with this variable. On the one hand, sociological theory posits that urbanization tends to weaken interpersonal bonds (Hoffman-Martinot 1994), therefore depressing turnout but, on the other hand, higher levels of education seem to be related to more turnout.

The empirical model also includes a set of institutional variables traditionally found in turnout studies. We use a standard measure of closeness of the elections, defined as the difference in vote percentages between the largest party and its closest challenger (Winning margin). There is ample evidence regarding the importance and the positive effect of competiveness on turnout (Geys 2006a). In our empirical model, for legislative elections this

\footnotetext{
${ }^{13}$ However, some comparative studies report the opposite relationship. For instance, Franklin (2004) found a negative effect on turnout of the percentage of the population with a college degree.
} 
is a district measure, as deputies in Portugal are elected by district, while for local elections it is constructed by municipality, as all local government branches are elected for the municipality. With similar geographical differences between local and national elections, we introduce the Laakso and Taegepera (1979) index for the effective number of political parties. Theoretically, there is no consensus on whether fragmentation can be expected to increase or decrease political participation. Geys (2006a) reviews the aggregate-level literature on turnout and concludes that on this matter results are inconclusive.

Another political indicator used is a dummy variable that takes the value of one when a local government is controlled by the party that holds power at the national level, and zero otherwise (Same party as national). This simultaneous government variable pinpoints the municipalities that exhibit the maximum clarity regarding the responsibility hypothesis, therefore enabling us to check if the reward/punishment mechanism associated with government voting also affects turnout. If so, the expected sign is negative, and reinforces the idea that turnout and government voting are linked. We also link the past government vote with current turnout by introducing in the empirical model for the legislative elections the votes received by the government in the previous election. We expect a negative effect on turnout, as some of the people that supported the government may be unhappy with its performance and find no credible alternative, therefore opting to abstain in the coming election. This means that the more overwhelming an electoral victory is the more it tends to depress future turnout.

Finally, one particular point of difference between local and national elections in Portugal is the possibility of finding groups of citizens running alongside organized parties in municipal elections. We introduce a dummy variable to control for the presence of these 
groups in local elections. Descriptive statistics for all variables used are found in the appendix.

Given the dynamic structure of the model, it is not appropriate to estimate equation (1) using OLS. In both the fixed and random effects settings, the lagged dependent variable is correlated with the error term, even if we assume that the disturbances are not themselves autocorrelated. According to Arellano and Bond (1991), this implies inconsistent estimates of the model, when, as in both our two samples, there is a clear dominance of cross sections (278 municipalities) over time periods (ten legislative or eight municipal elections). These authors developed a Generalized Method of Moments (GMM) estimator that solves the problems referred to above. First differencing (1) removes the individual effects $\left(v_{i}\right)$ and produces an equation that is estimable by instrumental variables. In this paper, we use the extended version of the GMM estimator proposed by Arellano and Bover (1995) and Blundell and Bond (1998), the System-GMM estimator for linear dynamic panel data models.

\section{Panel data empirical results}

Table 1 reports the results of system-GMM estimations ${ }^{14}$ for turnout at legislative and municipal elections, from 1979 to 2005 . Since data for economic variables at the municipal and regional levels start later than 1979 , we begin our analysis by estimating regressions without those variables, so that the entire sample period could be considered and the number of observations would be maximized. Thus, in the estimations whose results are

\footnotetext{
${ }^{14}$ Two-step results using robust standard errors corrected for finite samples are reported. The number of observations, municipalities and instruments, and the results of the Hansen and autocorrelation tests are reported at the foot of the table. It is worth noting that, in all estimations of tables 1, 2 and 3, the Hansen test never rejects the validity of the over-identifying restrictions, and autocorrelation of second order is always rejected. Thus, all our system-GMM estimations meet the requirements set forth by Arellano and Bond (1991) for the validity of GMM estimations of dynamic panel data models.
} 
reported in Table 1, only lagged turnout and the vectors of social and institutional variables described in the previous section were considered.

\section{-- Insert Table 1 about here --}

The results for legislative elections (see Column 1) indicate that turnout tends to be lower in municipalities with higher illiteracy rates, where the mayor belongs to the party that leads the national government, and where the national government obtained larger vote shares in previous elections. They also show that turnout is persistent, that is, turnout at previous elections is strongly and positively related to turnout in the current elections (the estimated coefficient is 0.8 ). All of these results conform to our expectations. Finally, turnout does not seem to be affected by demographic variables, the winning margin, and the number of effective parties. The insignificance of the coefficients estimated for the last two of those variables may be due to the fact that, for legislative elections, they are calculated at the district level.

Column 2 reports the results of the estimation for municipal elections. Results are similar to those obtained in Column 1 for all variables that were statistically significant, except simultaneous governing, which is no longer significant. Now, all demographic variables seem to affect turnout, which increases with larger percentages of the population over 65 years old, and is negatively related to the percentage of the population employed in the tertiary sector. The relationship with population density is also found to be negative thus supporting Downs's (1957) claim, as in smaller areas voters are more likely to affect the electoral result. However, because this effect is present only at municipal elections, another possibility is the closer proximity between voters and candidates for mayor found in smaller municipalities. 
Finally, the results for the winning margin point to an increase in turnout when elections are more competitive (i.e., a smaller vote difference between the two top votewinning parties), a result in accordance with theoretical expectations and general empirical evidence. As to fragmentation, there are strong theoretical arguments supporting both positive and negative effects. Our results are supportive of the latter, as they show that a larger effective number of parties reduces turnout in Portugal. Jackman (1987) argues that, under given electoral rules, more fragmentation increases the need for coalition formation, thus decreasing the influence voters have on government formation. Additionally, more parties increase the complexity of the electoral choice (Blais and Dobrozynska 1998) and add extra information costs (Hoffman-Martinot 1994) that can discourage voters from going to the polls.

Economic variables are included in the estimations of Table 2 (legislative elections) and Table 3 (municipal elections). Each estimation of columns 1 to 3 includes the national unemployment rate and two municipal/regional economic variables in quadratic form. Column 1 of Table 2 reports the results obtained for turnout at legislative elections when regional (NUTS III) unemployment and real GDP are included. ${ }^{15}$ Higher national unemployment rates are associated with higher turnout, which provides evidence in favor of the mobilization approach (Schlozman and Verba 1979; Lau 1982; Rosenstone 1992). The regional (NUTS III) unemployment rate seems to have a U-shaped relationship with turnout (negative sign for the level and positive sign for the squared level). Thus, lower rates of regional unemployment have a negative effect on turnout but, as unemployment increases, the effect becomes positive. The turning point is at an estimated unemployment rate of

\footnotetext{
${ }^{15}$ Since regional GDP data are available only from 1991 onwards, the number of observations is considerably (about one half) smaller than in the estimation of Column 1 of Table 1.
} 
$7.46 \%$, in column 1 , and of $7.59 \%$, in column 3 . Real GDP does not seem to affect turnout, when unemployment is taken into account.

\section{-- Insert Table 2 about here --}

The average marginal effects of the unemployment rate on turnout are illustrated in Figure 1 . There is a statistically significant negative marginal effect for unemployment rates below $6 \%$, and a significant positive marginal effect for rates above $10 \%$. As indicated in the previous paragraph, the marginal effect is zero at a rate of $7.46 \%$.

\section{-- Insert Figure 1 about here --}

In the estimation of Column 2 of Table 2, regional unemployment and GDP were replaced with the employment rate and real wages in the municipality. ${ }^{16}$ As expected, there is evidence of an inverted $U$-shaped relationship between employment and turnout, with the turning point at an employment rate of $35 \%$. The growth rate of real wages in the municipality does not seem to affect turnout. The regional (NUTS III) unemployment rate and the municipal sales index were used in the estimation of Column $3 .{ }^{17}$ As expected, the former has a U-shaped relationship with turnout (as in Column 1), while the latter has an inverted U-shaped relationship. ${ }^{18}$ Finally, the estimation of Column 4 includes the linear terms of all economic variables. Regional real GDP and municipal employment seem to be positively related to turnout. The absence of statistical significance for the regional unemployment rate may be due to the omission of the squared term, as the results of

\footnotetext{
${ }^{16}$ Data are available from 1985 onwards. Relative to the estimation of column 1, we gain one election for 275 municipalities.

${ }^{17}$ Since the municipal sales index is available only from 1992 onwards, this is the estimation with the smallest number of observations: we lose one election relative to column 1, and two elections relative to column 2 .

${ }^{18}$ The empirical evidence supporting the existence of non-linear effects of economic performance on turnout is practically the same when economic variables are mean-differenced in order to reduce the correlation between the linear and the quadratic terms. These results, not shown here, are available from the authors upon request. The turning point for the sales index is at 340, which is well above the sample maximum (160). Thus, for realistic values, turnout is increasing in the sales index and the effect essentially is linear.
} 
columns 1 and 3 clearly support the existence of a U-shaped relationship between the regional (NUTS III) unemployment rate and turnout.

Regarding the remaining explanatory variables, the most robust results are that turnout is persistent and that simultaneous governments reduce turnout. Greater competitiveness now seems to decrease turnout in columns 2 to 4 , a result lacking theoretical explanation but one that some studies report (see Kirchgässner and Himmern 1997). ${ }^{19}$ The votes obtained by the national government in the previous election seem to increase turnout in the current election (see columns 1, 3 and 4). This result is a bit strange, as it is the opposite of the one obtained in Table 1. Finally, the remaining independent variables are statistically significant only in one or two estimations, which may indicate that their relationship to turnout is not robust.

Table 3 shows the results obtained for municipal elections. Contrary to what happened for legislative elections, the national unemployment rate does not seem to affect voter participation. Although some voters may wish to reward/penalize the national government in municipal elections, it is not likely that the mobilization effect is of a magnitude comparable to that at legislative elections, when voters are judging the national government directly.

\section{-- Insert Table 3 about here --}

As happened for legislative elections, there is evidence of a $\mathrm{U}$-shaped relationship between regional unemployment rates and turnout (see columns 1 and 3 ). Thus, in municipal elections, voters tend to pay more attention to regional (NUTS III) unemployment, which is more closely related to municipal economic performance than national

\footnotetext{
${ }^{19}$ As our results seem to be in accordance with theoretical expectations at municipal elections, this surprising result for legislative elections may be due to the fact that we are using municipal data, but our measure of competitiveness is district-based.
} 
unemployment rates. $^{20}$ The absence of statistical significance for the regional unemployment rate in column 4 may be due to the omission of the squared term. Regional real GDP, municipal employment, municipal real wages, and the municipal sales index do not seem to affect turnout, as none of these variables is statistically significant in the estimations of Table 3. Concerning the other explanatory variables, there is robust evidence that turnout is persistent, that it increases with larger shares of the population over 65 years old, greater competitiveness, and in municipalities where lists of independent citizens run for office. Turnout falls with larger percentages of workers in the tertiary sector, a larger effective number of parties, and with simultaneous governments. Population density and the illiteracy rate are statistically significant only in column 2, both with a negative sign.

In an overall assessment, although unemployment seems to matter in both first- and second-order elections, our results for the economic variables are generally more robust for legislative elections. The opposite occurs with respect to institutional and sociodemographic variables; they seem to play a more important role in municipal elections. In light of the responsibility hypothesis, the first assessment makes sense, and, as to the second, it seems that different elections provide different stimuli to voters.

\section{Cross-section empirical results}

This section uses different datasets in order to test for the effects of parish (freguesia) and municipal level unemployment rates in turnout at the 2001 municipal elections and at the 2002 legislative elections. Yearly unemployment data are not available at the parish level, but because 2001 was a census year, it is possible to obtain this data and test the effect of this important economic variable at the lowest level of aggregation.

\footnotetext{
${ }^{20}$ The turning points are at unemployment rates of $7.54 \%$ (column 1 ) and $7.18 \%$ (column 3 ). These values are very similar to those obtained in the estimations for legislative elections (see Table 2).
} 
We made two changes to the model estimated in the previous section. First, the percentage of the municipal population in the tertiary sector was replaced by a dummy variable, Urban Areas, which takes the value of one for the parishes that are essentially of urban nature, and zero for rural ones. Second, instead of the percentage of the municipal population over 65 years old, we use the percentage of retired people in each parish. They are very similar measures, and the substitution was made because these were the closest proxies we could find in the census data. In the regressions for legislative elections, we omitted the closeness measure and the number of parties because, as they are measured at the district level, their variability would be very small in a cross section of parishes (there would be only 18 different values for each of these variables).

We use three alternative estimation methods that deal with the typical problem of heteroscedasticity found in cross-section analysis. ${ }^{21}$ The first is the standard OLS regression with robust standard errors. The second is the weighted least squares (WLS) method proposed by Madalla (1983), which identifies the heteroscedastic process and proposes a logistic transformation of the dependent variable. ${ }^{22}$ This method takes into account the population differences between parishes, thus yielding more efficient estimators than OLS. In the third method, after the WLS, we use a Feasible Generalized Least Square $(F G L S)^{23}$ in order to control for other unknown causes of heteroscedasticity. These last two methods are less vulnerable to heteroscedasticity than OLS.

The results of cross-section regressions for turnout at the parish (freguesia) level in Portuguese legislative elections are reported in Table 4. Since OLS results are less reliable

\footnotetext{
${ }^{21}$ It is necessary to account for heteroscedasticity because both the Breusch-Pagan and the White tests rejected the homoscedasticity assumption in our model.

${ }^{22}$ Turn $=\log \left(\right.$ Turn $_{i} /\left(1-\right.$ Turn $\left.\left._{i}\right)\right)$. See Dubin and Kaslow (1996) for an application of this method.

${ }^{23}$ Starting with the estimated logistic model, we correct for other potential sources of heteroscedasticity using the feasible generalized least square method proposed by Wooldridge (2003).
} 
than WLS and WLS/FGLS results, our comments concentrate on the latter two methods. The WLS results provide evidence of a U-shaped relationship between unemployment rates at the parish level and turnout. Considering that the turning point is at an unemployment rate of $17.9 \%$, for most cases only the negative effect matters. This is what the WLS/FGLS results indicate, as squared unemployment is not statistically significant in column 3 . Thus, higher unemployment at the parish level had essentially a demobilizing effect in the 2002 legislative elections.

\section{-- Insert Table 4 about here --}

The WLS/FGLS results indicate that growth in wages at the parish level has an inverted U-shaped relationship with turnout, with a turning point at around $3 \%$. Concerning the other independent variables, turnout is persistent, and it declines in urban areas, with higher illiteracy rates, and with the votes obtained by the national government in the previous election. The WLS/FGLS estimation results also indicate that turnout may increase with simultaneous governments and with larger percentages of retired people.

\section{-- Insert Table 5 about here --}

The cross-section results for municipal elections are reported in Table 5. The WLS and WLS/FGLS support the existence of a U-shaped relationship between unemployment and turnout, ${ }^{24}$ which is in line with the panel data results reported in Table 3 . There is also evidence that higher wages increase turnout. In this case, the mobilization effect would be to reward the local government. Furthermore, turnout is persistent, it increases with simultaneous governments, with larger percentages of retired people, and when lists of

\footnotetext{
${ }^{24}$ The turning points are at unemployment rates of $15.3 \%$ (WLS) and $14.3 \%$ (WLS/FGLS).
} 
independent citizens run alongside organized political parties. Finally, turnout seems to decrease in urban areas and to increase with competitiveness.

Finally, we conclude our empirical analysis with an extension of the turnout model of Geys and Heyndels (2006) for the Flemish Belgian municipalities. The aim is to check whether our results regarding the non-linear effects of economic variables are unique or not to the Portuguese case. Table 6 presents the results, and the variables' names used by the above-referenced authors are indicated in parentheses. The results reported in the first column are those of column 1 of Table 3 of Geys and Heyndels (2006), ${ }^{25}$ where unemployment (UNEM) is not statistically significant. In column two of Table 6, we introduce this variable in quadratic form, by adding the squared unemployment rate to the list of explanatory variables. The results show that both coefficients related to unemployment are statistically significant, and their respective signs are in accordance with our theoretical expectations and our empirical results for Portugal. That is, unemployment also had a non-linear (U-shaped) relationship with turnout in the 2000 Flemish municipal elections, with the turning point at an unemployment rate of $4 \%$. This suggests that our findings may be more than an idiosyncrasy of Portuguese voters or of a modeling whim. Thus, the way in which economic variables, especially unemployment, have been modeled in previous empirical studies may help explain why several of them have concluded that the economic environment does not affect turnout.

-- Insert Table 6 about here --

\footnotetext{
${ }^{25}$ In the estimations of Table 6, we used the econometric methodology adopted by Geys and Heyndels (2006), which essentially corresponds to our WLS.
} 


\section{Conclusion}

There is an extensive literature focusing on voter participation, and empirical studies have been able to identify a long list of variables that affect turnout. Nevertheless, the effect of economic performance on turnout is still an unsettled issue. There are two theoretical explanations for the effect of economic conditions on turnout which suggest opposing effects (mobilization versus withdrawal effects), and the empirical evidence has been mixed. Thus, there still is no consensus as to whether worse economic performance fosters or depresses turnout. In fact, several researchers argue that the economy does not affect voter participation at all.

This paper's main contribution to the literature is to test the hypothesis that both withdrawal and mobilization effects exist simultaneously, and that different degrees of adverse economic conditions provide different stimuli to voters. Concretely, we hypothesize that turnout is higher both in good and bad times, a mobilization effect, as more people will want to express their satisfaction/dissatisfaction with the economic performance achieved by the incumbent government. Participation rates are expected to be lower if the economy is neither too hot nor too cold, a withdrawal effect that may be due to economic issues being less salient for voters. These effects of the economy on turnout are consistent with the theory of expressive voting.

Using four extensive datasets, we perform system-GMM panel data estimations and OLS, WLS and WLS/FGLS cross-section estimations for turnout at Portuguese legislative and municipal elections. Our results provide robust empirical evidence indicating that economic conditions affect voter participation rates. Moreover, the results support the hypothesis that the economy has non-linear effects on turnout. That is, the presence and magnitude of the mobilization or withdrawal effects depend on the severity of economic conditions. We 
find a U-shaped relationship between unemployment rates and turnout: at low rates, unemployment seems to have withdrawal effects, while for higher rates (above $7.5 \%$ ) it has mobilization effects. Employment rates and real wages are also found to have non-linear effects on turnout, with the expected signs (consistent with an inverted U-shaped relationship). Similar results are obtained when extending the turnout model of Geys and Heyndels (2006) to the 2000 Flemish municipal elections. Specifically, when the squared unemployment rate is added to their model, both the linear term (which was not significant in their study) and the squared term are statistically significant, with the expected signs. That is, we find evidence of a non-linear (U-shaped) effect of the unemployment rate on turnout, indicating that these non-linear effects are not a peculiarity of the Portuguese case, and may be present in other countries. Thus, the mixed results for the effects of economic performance on turnout obtained in previous studies may be due to the fact that nonlinearities were not tested for or were not properly taken into account.

\section{Acknowledgments}

The authors thank Jared P. Barton, two anonymous referees, and participants at the $2^{\text {nd }}$ World Conference of the Public Choice Society and at the Martin Paldam Workshop for very useful comments. We also thank Benny Geys for sharing the dataset on turnout at the 2000 Flemish municipal elections. The authors are also thankful for the financial support provided by ERDF funds through the Operational Program Factors of Competitiveness - COMPETE and by the Portuguese Foundation for Science and Technology (FCT) under research grants PTDC/EGE-ECO/118501/2010 and PEst-C/EGE/UI3182/2011. 


\section{Appendix}

Table A1. Descriptive statistics: panel data (legislative elections)

\begin{tabular}{lcccrr}
\hline Variable & Obs & Mean & Std. Dev. & Min & \multicolumn{1}{c}{ Max } \\
\hline Turnout & 3033 & 71.9642 & 10.12391 & 48.06974 & 94.1557 \\
National unemployment rate & 2780 & 6.693509 & 1.518209 & 4.07 & 8.86 \\
Unemployment rate & 1390 & 5.972381 & 2.454735 & 1.57 & 14.3 \\
Real GDP & 1390 & 3.687086 & 6.205422 & 0.242127 & 40.50569 \\
Employment rate & 1934 & 16.03878 & 10.02724 & 1.029703 & 87.61473 \\
Growth in wages & 1656 & 1.759789 & 4.826512 & -26.9679 & 26.07056 \\
Sales Index & 1103 & 3.626564 & 10.24918 & 0.2 & 160.14 \\
Population density & 2758 & 2.868164 & 8.895024 & 0.058178 & 96.35504 \\
\% Population over 65 years old & 2757 & 17.38805 & 5.961829 & 5.326595 & 42.02425 \\
\% Population tertiary sector & 2750 & 41.91003 & 15.61383 & 9.155093 & 85.56738 \\
Illiteracy rate & 2750 & 19.05551 & 8.725882 & 3.728859 & 54.98336 \\
Winning margin & 2758 & 16.99795 & 11.81036 & 0.047844 & 45.81835 \\
Effective number of parties & 2759 & 3.156304 & 0.639557 & 2.035882 & 5.080246 \\
Same party as national & 2755 & 0.408349 & 0.491618 & 0 & 1 \\
Government share of votes & 3033 & 37.01825 & 15.5527 & 5.453149 & 85.45291 \\
\hline
\end{tabular}

Table A2. Descriptive statistics: panel data (municipal elections)

\begin{tabular}{lcrrrr}
\hline Variable & Obs. & Mean & Std. Dev. & Min. & \multicolumn{1}{c}{ Max. } \\
\hline Turnout & 2480 & 66.97211 & 7.358434 & 36.7938 & 92.64069 \\
National unemployment rate & 2224 & 6.450909 & 1.522798 & 4.08 & 8.86 \\
Unemployment rate & 1112 & 6.249824 & 2.445535 & 1.67 & 12.03128 \\
Real GDP & 1112 & 3.703672 & 6.223877 & 0.247569 & 40.50569 \\
Sales Index & 1103 & 3.626618 & 10.1494 & 0.19 & 151.85 \\
Growth in wages & 1381 & 0.463713 & 5.166349 & -41.1102 & 21.24216 \\
Employment rate & 1656 & 16.26608 & 10.05406 & 1.029703 & 90.1767 \\
Population density & 2205 & 2.8496 & 8.804773 & 0.058178 & 96.36732 \\
\% Population over 65 years old & 2205 & 17.62704 & 6.012745 & 5.353324 & 42.02425 \\
\% Population tertiary sector & 2203 & 42.82315 & 15.4991 & 9.155093 & 84.91925 \\
Illiteracy rate & 2203 & 18.52168 & 8.560274 & 3.728859 & 54.98336 \\
Winning margin & 2206 & 19.86058 & 14.66725 & 0.018191 & 87.92598 \\
Effective Number of Parties & 2206 & 2.654976 & 0.512906 & 1.186214 & 4.68719 \\
Same party as national & 2223 & 0.421503 & 0.493911 & 0 & 1 \\
Groups of citizens & 2221 & 0.021612 & 0.145445 & 0 & 1 \\
\hline
\end{tabular}


Table A3. Descriptive statistics: cross section

\begin{tabular}{lcccrr}
\hline Variable & Obs. & Mean & Std. Dev. & Min. & Max. \\
\hline Turnout (Municipal Elections) & 4035 & 68.58307 & 9.713741 & 32.45 & 95.84 \\
Turnout (Legislative Elections) & 4037 & 61.37206 & 7.7184 & 20.41 & 88.62 \\
Growth in wages & 4037 & 1.445557 & 2.358816 & -7.95722 & 10.33196 \\
Unemployment rate & 4037 & 7.007629 & 4.831338 & 0 & 38.3 \\
Urban Areas & 4037 & 0.239039 & 0.426549 & 0 & 1 \\
Illiteracy rate & 4037 & 14.97067 & 7.946764 & 1.3 & 53.6 \\
Simultaneous government & 4037 & 0.482537 & 0.499757 & 0 & 1 \\
Population density & 4036 & 0.521825 & 1.872446 & 0.0014 & 35.54 \\
\% Retired people & 4037 & 25.09507 & 10.54528 & 0 & 85.6 \\
Winning margin (municipal elections) & 4035 & 25.42264 & 18.28788 & 0 & 93.62 \\
Groups of citizens & 4035 & 0.109046 & 0.311735 & 0 & 1 \\
Government votes (previous election) & 4020 & 42.05093 & 12.90834 & 2.94 & 88.39 \\
\hline
\end{tabular}




\section{References}

Aidt, T.S. (2000). Economic voting and information. Electoral Studies, 19, 349-362.

Arellano, M. \& Bond, S. (1991). Some tests of specification for panel data: Monte Carlo evidence and an application to employment equations. The Review of Economic Studies, 58, 277-297.

Arellano, M. \& Bover, O. (1995). Another look at the instrumental variable estimation of error-component models. Journal of Econometrics, 68, 29-51.

Blais, A. (2000). To vote or not to vote: the merits and limits of rational choice theory. Pittsburgh: University of Pittsburgh Press.

Blais, A. \& Dobrzynska, A. (1998). Turnout in electoral democracies. European Journal of Political Research, 33, 239-61.

Blais, A. (2006). What affects voter turnout? Annual Review of Political Science, 9, 111-25.

Blundel, R. \& Bond, S. (1998). Initial conditions and moments restrictions in dynamic panel data models. Journal of Econometrics, 87, 11-143.

Buchanan, J.M. (1954). Individual choice in voting and the market. Journal of Political Economy, 62, 334-343.

Caldeira, G., Patterson, S., \& Markko, G. (1985). Getting out the vote. Journal of Politics, 47(3), 490-509.

Downs, A. (1957). An economic theory of democracy, New York: Harper Collins.

Dubin, J. \& Kaslow, G. (1996). Comparing absentee and precint voters: a view over time. Political Behavior, 18(4), 369-92.

Fiorina, M.P. (1976). The voting decision: instrumental and expressive aspects. Journal of Politics, 38, 390-413. 
Fiorina, M.P. (1978). Economic retrospective voting in American national elections: a microanalysis. American Journal of Political Science, 22(2), 426-43.

Fornos, C., Power, T., \&Garand, J. (2004). Explaining voter turnout in Latin America, 1980 to 2000. Comparative Political Studies, 37(8), 909-40.

Franklin, M. (2004). Voter turnout and the dynamics of electoral competition in established democracies since 1945. New York: Cambridge University Press.

Freire, A. \& Magalhães, P. (2002). A abstenção eleitoral em Portugal. Lisboa: Imprensa de Ciências Sociais

Geys, B. (2006a). Explaining voter turnout: a review of aggregate-level research. Electoral Studies, 25, 637-663.

Geys, B. (2006b). "Rational" theories of voter turnout: a review. Political Studies, 4, 16-35.

Geys, B. \& Heyndels, B. (2006). Disentangling the effects of political fragmentation on voter turnout: the Flemish municipal elections. Economics \& Politics, 18(3), 367-387.

Hamlin, A. \& Jennings, C. (2011). Expressive political behavior: foundations, scope and implications. British Journal of Political Science, 41(3), 645-670.

Hillman, A.L. (2010). Expressive behavior in economics and politics. European Journal of Political Economy, 26, 403-418.

Hoffman-Martinot, V. (1994). Voter turnout in French municipal elections. In L. Lopez Nieto (Ed.), Local elections in Europe (pp 13-42). Barcelona: Institut de Ciènces Politiques I Sociales.

Honaker, J. \& King, G. (2010). What to do about missing values in time series cross-section data. American Journal of Political Science, 54(2), 561-581.

Jackman, R. (1987). Political institutions and voter turnout in the industrial democracies. American Journal of Political Science, 37, 405-23. 
Jackman, R. \& Miller, R. (1995). Voter turnout in the industrial democracies during the 1980s. Comparative Political Studies, 27(4), 467-469.

Kirchgässner, G. \& Himmern, A. (1997). Expected closeness and turnout: an empirical analysis for the German general elections, 1983-1994. Public Choice, 91, 2-25.

Kostadinova, T. (2003). Voter turnout dynamics in post-communist Europe. European Journal of Political Research, 42:6, 467-92.

Laakso, M. \& Taegepera, R. (1979). The effective number of parties: a measure with application to Western Europe. Comparative Political Studies, 12(1), 3-27.

Lau, R. (1982). Negativity in political perceptions. Political Behavior, 4,353-78.

Lijphart, A. (1997). Unequal participation: democracy's unresolved dilemma. American Political Science Review, 91(1), 1-14.

Maddala, G. (1983). Limited dependent and qualitative variables in econometrics. Cambridge, UK: Cambridge University Press.

Nannestad, P. \& Paldam, M. (1994). The VP-function: a survey of the literature on vote and popularity after 25 years. Public Choice, 79, 213-45.

Norris, P. (2004). Electoral engineering: voting rules and political behavior. New York: Cambridge University Press.

Paldam, M. (2004). Are vote and popularity functions economically correct?, in C.K. Rowley \& F. Schneider (Eds.), The encyclopedia of Public Choice (pp. 49-59). Netherlands: Kluwer Academic.

Powell, G. (1986). American voter turnout in comparative perspective. American Political Science Review, 80(1), 17-43.

Radcliff, B. (1992). The welfare state, turnout, and the economy: a comparative analysis. American Political Science Review, 86(2), 444-54. 
Rosenstone, S. (1982). Economic adversity and voter turnout. American Journal of Political Science, 26(1), 25-46.

Schlozman, K. \& Verba, S. (1979). Injury to insult. Cambridge: Harvard University Press.

Wolfinger, R. \& Rosenstone, S. (1980). Who votes? New Haven: Yale University Press.

Wooldridge, J. (2003). Introductory econometrics: a modern approach. Mason, OH: South Western Publishers. 
Table 2. Turnout at legislative elections - GMM panel estimates

\begin{tabular}{|c|c|c|c|c|}
\hline & $(1)$ & $(2)$ & (3) & (4) \\
\hline \multirow[t]{2}{*}{ National unemployment } & $0.935 * * *$ & $0.869 * * *$ & $1.065^{* * *}$ & $0.979 * * *$ \\
\hline & $(11.867)$ & $(12.486)$ & $(13.151)$ & $(11.835)$ \\
\hline \multirow[t]{2}{*}{ Unemployment } & $-0.403 * * *$ & & $-0.820 * * *$ & -0.046 \\
\hline & $(-3.408)$ & & $(-6.095)$ & $(-0.987)$ \\
\hline \multirow[t]{2}{*}{ Squared unemployment } & $0.027 * * *$ & & $0.054 * * *$ & \\
\hline & $(3.346)$ & & $(5.771)$ & \\
\hline \multirow[t]{2}{*}{ Real GDP } & 0.007 & & & $0.034 * * *$ \\
\hline & $(0.218)$ & & & $(2.978)$ \\
\hline \multirow[t]{2}{*}{ Squared real GDP } & 0.000 & & & \\
\hline & $(0.672)$ & & & \\
\hline \multirow[t]{2}{*}{ Employment rate } & & $0.070 * * *$ & & $0.022 *$ \\
\hline & & $(2.835)$ & & $(1.862)$ \\
\hline \multirow[t]{2}{*}{ Squared employment rate } & & $-0.001 * *$ & & \\
\hline & & $(-1.982)$ & & \\
\hline \multirow[t]{2}{*}{ Growth in wages } & & -0.000 & & 0.016 \\
\hline & & $(-0.028)$ & & $(0.686)$ \\
\hline \multirow{2}{*}{ Squared growth in wages } & & 0.001 & & \\
\hline & & $(1.426)$ & & \\
\hline \multirow[t]{2}{*}{ Sales index } & & & $0.068 * * *$ & -0.008 \\
\hline & & & (3.015) & $(-1.055)$ \\
\hline \multirow[t]{2}{*}{ Squared sales index } & & & $-0.0001 * * *$ & \\
\hline & & & $(-2.831)$ & \\
\hline \multirow[t]{2}{*}{ Population density } & -0.004 & 0.015 & 0.002 & 0.005 \\
\hline & $(-0.583)$ & $(1.409)$ & $(0.208)$ & $(0.348)$ \\
\hline \multirow[t]{2}{*}{ \% Population over 65} & 0.042 & $0.079 * * *$ & -0.037 & -0.001 \\
\hline & $(1.624)$ & $(3.034)$ & $(-1.191)$ & $(-0.025)$ \\
\hline \multirow[t]{2}{*}{ \% Population tertiary sector } & -0.007 & $-0.027^{* * *}$ & -0.012 & $-0.020 * *$ \\
\hline & $(-0.782)$ & $(-3.311)$ & $(-1.303)$ & $(-1.998)$ \\
\hline \multirow[t]{2}{*}{ Illiteracy rate } & -0.031 & -0.040 & $0.058^{*}$ & 0.024 \\
\hline & $(-1.046)$ & $(-1.422)$ & $(1.674)$ & (0.609) \\
\hline \multirow[t]{2}{*}{ Winning margin (district) } & 0.007 & $0.015^{* *}$ & $0.037 * * *$ & $0.036 * * *$ \\
\hline & $(1.036)$ & $(2.037)$ & $(4.529)$ & $(3.978)$ \\
\hline \multirow[t]{2}{*}{ Eff. Number of Parties (district) } & -0.180 & $-0.852 * * *$ & -0.193 & -0.464 \\
\hline & $(-0.778)$ & $(-3.180)$ & $(-0.808)$ & $(-1.542)$ \\
\hline \multirow[t]{2}{*}{ Same party as national } & $-0.584 * * *$ & $-0.269 * *$ & $-0.320 * *$ & $-0.369 * *$ \\
\hline & $(-4.477)$ & $(-2.085)$ & $(-2.282)$ & $(-2.532)$ \\
\hline \multirow[t]{2}{*}{ Turnout (previous election) } & $0.702 * * *$ & $0.599 * * *$ & $0.650 * * *$ & $0.616^{* * *}$ \\
\hline & $(26.186)$ & $(23.022)$ & $(19.194)$ & $(17.987)$ \\
\hline \multirow[t]{2}{*}{ Gov. votes (previous election) } & $0.017^{* * *}$ & 0.002 & $0.026 * * *$ & $0.025 * * *$ \\
\hline & $(2.685)$ & $(0.320)$ & $(4.451)$ & (4.059) \\
\hline Observations & 1375 & 1650 & 1100 & 1100 \\
\hline Municipalities / Instruments & $275 / 259$ & $275 / 269$ & $275 / 262$ & $275 / 252$ \\
\hline Hansen Test & $263.3[0.144]$ & $268.2[0.192]$ & $254.7[0.306]$ & $252.9[0.177]$ \\
\hline AR(1) Test & $-6.112[0.00]$ & $-6.783[0.00]$ & $-5.30[0.00]$ & $-5.347[0.00]$ \\
\hline$A R(2)$ Test & $-0.0955[0.924]$ & $-0.422[0.192]$ & $-0.922[0.357]$ & $-1.473[0.141]$ \\
\hline
\end{tabular}


Table 3. Turnout at municipal elections - GMM panel estimates

\begin{tabular}{|c|c|c|c|c|}
\hline & (1) & (2) & (3) & (4) \\
\hline \multirow[t]{2}{*}{ National unemployment rate } & 0.031 & 0.061 & 0.051 & -0.132 \\
\hline & $(0.239)$ & $(0.583)$ & $(0.381)$ & $(-1.003)$ \\
\hline \multirow[t]{2}{*}{ Unemployment } & $-0.407^{*}$ & & $-0.488 * *$ & 0.008 \\
\hline & $(-1.756)$ & & $(-2.210)$ & $(0.183)$ \\
\hline \multirow[t]{2}{*}{ Squared unemployment } & $0.027^{*}$ & & $0.034 * *$ & \\
\hline & $(1.783)$ & & $(2.337)$ & \\
\hline \multirow[t]{2}{*}{ Real GDP } & -0.061 & & & 0.009 \\
\hline & $(-1.162)$ & & & $(0.608)$ \\
\hline \multirow[t]{2}{*}{ Squared real GDP } & 0.002 & & & \\
\hline & (1.64) & & & \\
\hline \multirow[t]{2}{*}{ Employment rate } & & -0.047 & & 0.022 \\
\hline & & $(-1.611)$ & & $(1.384)$ \\
\hline \multirow[t]{2}{*}{ Squared employment rate } & & 0.001 & & \\
\hline & & $(1.316)$ & & \\
\hline \multirow[t]{2}{*}{ Growth in wages } & & -0.004 & & 0.002 \\
\hline & & $(-0.216)$ & & $(0.131)$ \\
\hline \multirow[t]{2}{*}{ Squared growth in wages } & & -0.001 & & \\
\hline & & $(-0.443)$ & & \\
\hline \multirow[t]{2}{*}{ Sales index } & & & 0.025 & -0.018 \\
\hline & & & $(1.006)$ & $(-1.617)$ \\
\hline \multirow[t]{2}{*}{ Squared sales index } & & & -0.000 & \\
\hline & & & $(-1.246)$ & \\
\hline \multirow[t]{2}{*}{ Population density } & -0.006 & $-0.026 * * *$ & -0.003 & 0.001 \\
\hline & $(-0.544)$ & $(-3.026)$ & $(-0.370)$ & $(0.094)$ \\
\hline \multirow[t]{2}{*}{ \% Population over 65} & $0.076^{*}$ & $0.133^{* * *}$ & $0.090 * *$ & $0.113^{* *}$ \\
\hline & $(1.930)$ & $(4.647)$ & $(2.296)$ & $(2.521)$ \\
\hline \multirow[t]{2}{*}{ \% Population tertiary sector } & $-0.035 * * *$ & $-0.066 * * *$ & $-0.039 * * *$ & $-0.033^{* * *}$ \\
\hline & $(-2.711)$ & $(-5.882)$ & $(-3.013)$ & $(-2.716)$ \\
\hline \multirow[t]{2}{*}{ Illiteracy rate } & 0.008 & $-0.055^{*}$ & -0.000 & -0.013 \\
\hline & $(0.192)$ & $(-1.748)$ & $(-0.007)$ & $(-0.283)$ \\
\hline \multirow[t]{2}{*}{ Winning margin (municipality) } & $-0.087 * * *$ & $-0.085^{* * *}$ & $-0.072 * * *$ & $-0.087 * * *$ \\
\hline & $(-10.165)$ & $(-6.528)$ & $(-5.671)$ & $(-9.697)$ \\
\hline \multirow[t]{2}{*}{ Eff. Number of Parties (municipality) } & $-1.972 * * *$ & $-1.765^{* * *}$ & $-1.536 * * *$ & $-2.113^{* * *}$ \\
\hline & $(-5.963)$ & $(-4.880)$ & $(-4.224)$ & $(-6.426)$ \\
\hline \multirow[t]{2}{*}{ Same party as national } & $-0.613^{* * *}$ & -0.171 & $-0.582 * * *$ & $-0.693 * * *$ \\
\hline & $(-2.903)$ & $(-0.883)$ & $(-2.741)$ & $(-3.258)$ \\
\hline \multirow[t]{2}{*}{ Groups of citizens } & $3.099 * * *$ & $3.210 * * *$ & $2.915 * * *$ & $2.953 * * *$ \\
\hline & $(5.251)$ & $(5.807)$ & $(4.868)$ & $(4.933)$ \\
\hline \multirow[t]{2}{*}{ Turnout (previous election) } & $0.779 * * *$ & $0.805^{* * *}$ & $0.803^{* * *}$ & $0.789 * * *$ \\
\hline & $(26.238)$ & $(40.819)$ & $(25.570)$ & $(23.654)$ \\
\hline Observations & 1100 & 1375 & 1100 & 1100 \\
\hline Municipalities / Instruments & $275 / 237$ & $275 / 269$ & $275 / 242$ & $275 / 229$ \\
\hline Hansen Test & $239.4[0.164]$ & $264.6[0.266]$ & $244.9[0.161]$ & $221.8[0.275]$ \\
\hline $\mathrm{AR}(1)$ Test & $-7.723[0.00]$ & $-8.186[0.00]$ & $-7.699[0.00]$ & $-7.687[0.00]$ \\
\hline$A R(2)$ Test & $-0.188[0.851]$ & $-0.863[0.388]$ & $-0.429[0.668]$ & $-0.315[0.753]$ \\
\hline
\end{tabular}


Table 4. Turnout at the 2002 Legislative elections

\begin{tabular}{|c|c|c|c|}
\hline & (1) & (2) & (3) \\
\hline VARIABLES & OLS & WLS & WLS/FGLS \\
\hline \multirow[t]{2}{*}{ Growth in wages } & 0.0241 & 0.00263 & $0.00454^{*}$ \\
\hline & (0.437) & (1.419) & $(1.923)$ \\
\hline \multirow[t]{2}{*}{ Squared growth in wages } & -0.0038 & -0.00038 & $-0.00075^{* *}$ \\
\hline & $(-0.517)$ & $(-1.471)$ & $(-2.282)$ \\
\hline \multirow[t]{2}{*}{ Unemployment } & -0.0153 & $-0.00572^{* * *}$ & $-0.00640 *$ \\
\hline & $(-0.363)$ & $(-2.600)$ & $(-1.762)$ \\
\hline \multirow[t]{2}{*}{ Squared unemployment } & 0.0007 & $0.00016^{* *}$ & 0.00009 \\
\hline & $(0.460)$ & $(2.046)$ & $(0.586)$ \\
\hline \multirow[t]{2}{*}{ Urban areas } & -0.2095 & $-0.01329 *$ & $-0.01458 *$ \\
\hline & $(-1.272)$ & $(-1.930)$ & $(-1.705)$ \\
\hline \multirow[t]{2}{*}{ Illiteracy rate } & $-0.0982 * * *$ & $-0.00380^{* * *}$ & $-0.00485^{* * *}$ \\
\hline & $(-5.354)$ & $(-3.863)$ & $(-5.017)$ \\
\hline \multirow[t]{2}{*}{ Same party as national } & 0.0028 & 0.01228 & $0.01521 *$ \\
\hline & $(0.013)$ & $(1.634)$ & $(1.878)$ \\
\hline \multirow[t]{2}{*}{ Population density } & $0.0525^{*}$ & $0.00164^{*}$ & 0.00061 \\
\hline & $(1.745)$ & $(1.670)$ & $(0.955)$ \\
\hline \multirow[t]{2}{*}{$\%$ Retired people } & $-0.0320 * *$ & 0.00049 & $0.00198 * *$ \\
\hline & $(-2.509)$ & $(0.572)$ & $(2.195)$ \\
\hline \multirow[t]{2}{*}{ Turnout (previous election) } & $0.7714^{* * *}$ & $0.03522^{* * *}$ & $0.03681^{* * *}$ \\
\hline & $(40.980)$ & $(41.513)$ & $(49.417)$ \\
\hline \multirow[t]{2}{*}{ Gov. votes (previous election) } & $-0.0316 * * *$ & $-0.00235^{* * *}$ & $-0.00268 * * *$ \\
\hline & $(-4.527)$ & $(-6.330)$ & $(-6.127)$ \\
\hline Observations & 4,019 & 4,019 & 4,019 \\
\hline Adjusted R-squared & 0.776 & 0.824 & 0.857 \\
\hline
\end{tabular}


Table 5. Turnout at the 2001 municipal elections

\begin{tabular}{lccc}
\hline & $(1)$ & $(2)$ & $(3)$ \\
VARIABLES & $\mathrm{OLS}$ & $\mathrm{WLS}$ & WLS/FGLS \\
\hline Growth in wages & 0.0512 & $0.0116^{*}$ & $0.01706^{* *}$ \\
& $(0.834)$ & $(1.773)$ & $(2.033)$ \\
Squared growth in wages & 0.0086 & -0.0012 & -0.00233 \\
& $(1.013)$ & $(-0.791)$ & $(-1.239)$ \\
Unemployment & $-0.1202^{*}$ & $-0.0215^{* * *}$ & $-0.02888^{* * *}$ \\
& $(-1.659)$ & $(-3.123)$ & $(-3.270)$ \\
Squared unemployment & 0.0032 & $0.0007^{* * *}$ & $0.00101^{* * *}$ \\
& $(1.164)$ & $(3.053)$ & $(3.025)$ \\
Urban areas & $-2.2410^{* * *}$ & $-0.0828^{* * *}$ & $-0.08354^{* * *}$ \\
& $(-6.458)$ & $(-5.118)$ & $(-4.908)$ \\
Illiteracy rate & 0.0121 & 0.0003 & 0.00078 \\
& $(0.485)$ & $(0.173)$ & $(0.379)$ \\
Same party as national & -0.4977 & $0.0478^{* *}$ & $0.06515^{* * *}$ \\
& $(-1.193)$ & $(1.988)$ & $(2.711)$ \\
Population density & -0.0423 & 0.0005 & -0.00012 \\
& $(-0.210)$ & $(0.108)$ & $(-0.030)$ \\
\% Retired people & $0.0432 * *$ & $0.0084^{* * *}$ & $0.01025^{* * *}$ \\
& $(2.424)$ & $(3.110)$ & $(3.762)$ \\
Winning margin (municipality) & $-0.0615^{* * *}$ & $-0.0018^{* * *}$ & $-0.00129 * *$ \\
& $(-6.976)$ & $(-3.762)$ & $(-2.368)$ \\
Groups of citizens & $2.3326^{* * *}$ & $0.1517^{* * *}$ & $0.18143^{* * *}$ \\
& $(3.878)$ & $(3.254)$ & $(3.219)$ \\
Turnout (previous election) & $0.8300^{* * *}$ & $0.0368^{* * *}$ & $0.03500^{* * *}$ \\
& $(41.931)$ & $(28.901)$ & $(26.439)$ \\
\hline Observations & 4,009 & 4,009 & 4,009 \\
Adjusted R-squared & 0.685 & 0.798 & 0.796 \\
\hline NOTES: All estimations include a constant term. $* * *$ & p $<0.01, * * p<0.05, *$ & $p<0.1 . ~ N u m b e r s ~ i n$ \\
$\quad$ parenthesis are t-statistics. & & & \\
& & &
\end{tabular}


Table 6. Turnout at the 2000 Flemish municipal elections

\begin{tabular}{lcc}
\hline VARIABLES & $\begin{array}{c}(1) \\
\text { Geys and Heyndels } \\
(2006)\end{array}$ & $\begin{array}{c}(2) \\
\text { Unemployment in } \\
\text { quadratic form }\end{array}$ \\
\hline Intercept & $4.892^{* * *}$ & $5.135^{* * *}$ \\
& $(22.52)$ & $(20.49)$ \\
Number of registered voters (REG) & -0.000 & -0.000 \\
& $(-1.12)$ & $(-1.38)$ \\
Population density (DENS) & $-0.0002^{* * *}$ & $-0.0002^{* * *}$ \\
& $(-4.06)$ & $(-4.06)$ \\
Migration as a \% of population (MIGR) & $-2.701^{* * *}$ & $-2.473^{* * *}$ \\
& $(-3.02)$ & $(-2.75)$ \\
Population over 65 as a \% of population (AGE) & $-2.010^{* * *}$ & $-2.079^{* * *}$ \\
& $(-3.69)$ & $(-3.83)$ \\
Per capita taxable income (Y) & $-0.033^{*}$ & -0.028 \\
& $(-1.90)$ & $(-1.59)$ \\
Income inequality (INCDIV) & $-0.007^{* * *}$ & $-0.009^{* * *}$ \\
& $(-2.80)$ & $(-3.29)$ \\
Unemployed as \% of population (UNEM) & -0.434 & $-0.096^{*}$ \\
& $(-0.27)$ & $(-1.91)$ \\
Squared UNEM & - & $0.012^{*}$ \\
& & $(1.92)$ \\
Municipalities in judicial areas where non- & $-0.112^{* *}$ & $-0.101^{* *}$ \\
voters are prosecuted (PROSEC) & $(-2.57)$ & $(-2.29)$ \\
Number of parties (NoP) & $-0.074^{* * *}$ & $-0.072^{* * *}$ \\
Size inequalities among parties (I) & $(-5.96)$ & $(-5.84)$ \\
& -0.045 & -0.039 \\
Observations & $(-0.58)$ & $(-0.51)$ \\
Adjusted R-squared & 307 & 307 \\
& 0.551 & 0.555 \\
\hline
\end{tabular}

NOTES: Column 1 replicates the results shown in Column 1 of Table 3 of Geys and Heyndels (2006).

$* * * p<0.01, * * p<0.05, * p<0.1$. Numbers in parenthesis are t-statistics. 
Figure 1. Average marginal effects of the unemployment rate

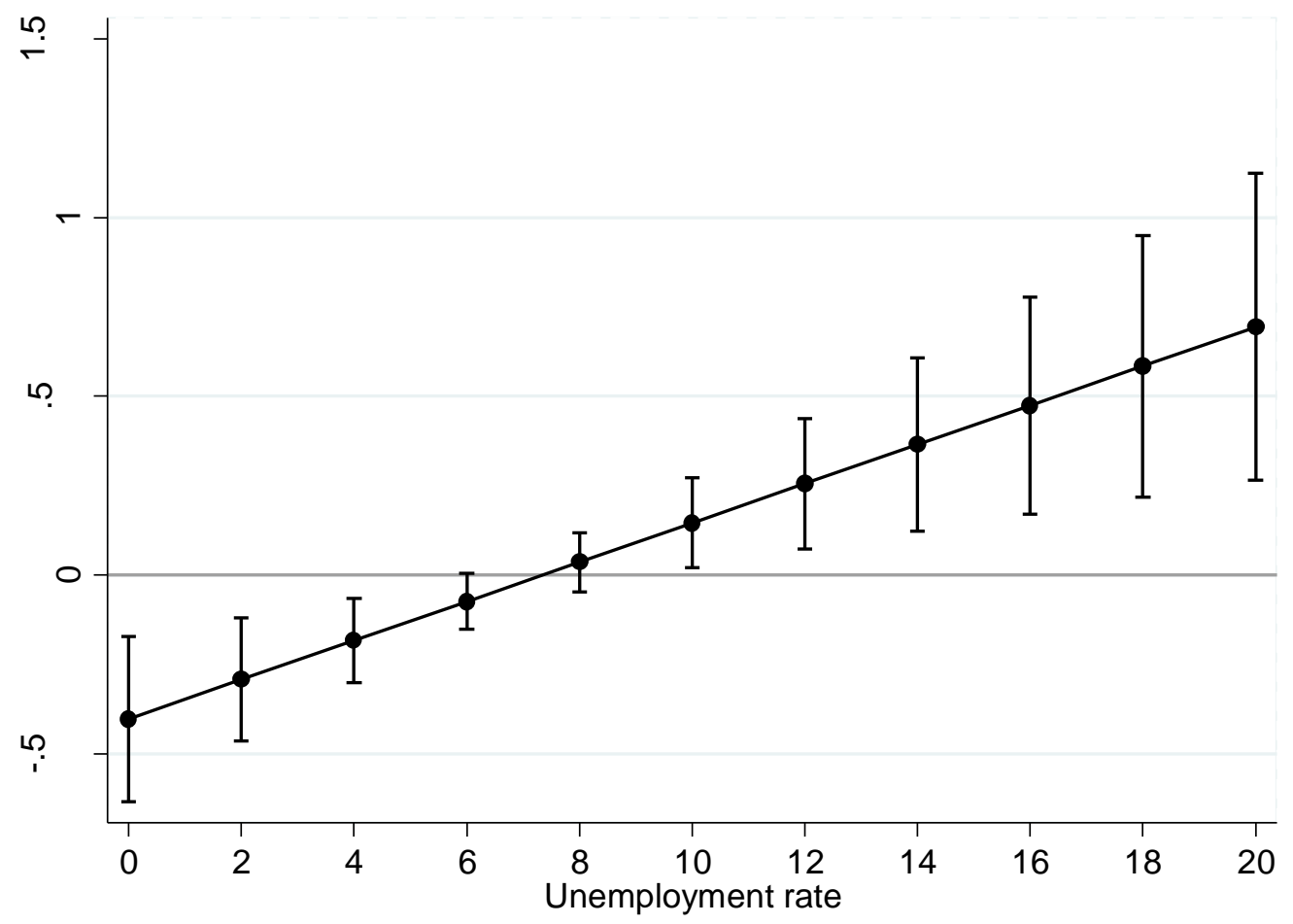

Note: This figure is based on the estimation whose results are reported in column 1 of Table 2. 